\title{
On the Analytic and Coalescent Conjugations in Pāli
}

\author{
YAMANAKA Yukio
}

\section{Preamble}

In the Middle Indic, including Pāli, we find many examples of the analytic and coalescent conjugations. The analytic conjugation means that a personal pronoun supplements or substitutes the verb ending of the conjugation; jahe aham "I want to throw away," Ja III 14,15*. In this example, jahe is an optative of "jahati." As the character of the uniform optative with its marker $-e$, the optative ending remains the same, i.e., whenever it stands for the first, second or third person singular, its ending might be unchanged. This is a contrast to the optative with -eyya-, whose endings inflect depending on persons. Because of the uniform ending of -e-optative, a personal pronoun begins to take over the function of the verb ending, in order to indicate, who is the agent of the sentence; jahe $\rightarrow$ jahe aham.

On the other hand, the coalescent conjugation means that a personal pronoun agglutinates after the verb ending, as if it were a part of the verb ending; puccheyyām'aham "I want to question," D I 51,3; nānutapeyy'aham "I am not going to regret," Ja IV 241,19*. From the coalescent conjugation, a new verb form is produced, i.e., -ham, derived from aham, substitutes -āmi (palāyaham "I escape," Ja II 340,9*; ramaham "I rejoice," Ja V 112,31*; anusāsaham, Ap 163,5). The appearances between these two conjugations are different, but they play a same grammatical roll, in which the personal pronoun supplements or substitutes the verb ending.

\section{Overview of Research History}

Smith (1932) focuses for the first time on this problem, thereby he insists that ramaham, anusäsaham the ending -ham of the both verbs are originated from the personal pronoun aham. 
Smith $(1932,170)$ argues also that the $-(a) h a m$-conjugation for the optative and preterit, instead of -am or -ämi, is observed generally in the Middle Indic; optative, ālabhe-ham, Aśoka Kalinga Separate Edicts, tișthe-ham, Mvu I 51,8; preterit, cāri 'ham, Thi 123. Furthermore, Smith $(1932,170)$ claims that this new verb form corresponds to the first-person ending -aũ of Apabhramśa. ${ }^{1)}$

The occurrences of the analytic and coalescent conjugations are found in the various Middle Indic texts. Consequently it is possible that this forms reflect the dialectal or colloquial language at that time. ${ }^{21}$

Smith himself categorizes the analytic/coalescent conjugations more precisely in CPD, s.v. aham under 2 Morphology A, p. 528. They are categorized into five, namely from $\alpha$ to $\varepsilon$ :

a) aham is seemingly pleonastic in a sentence (rājäham asmi, Sn 554).

$\beta$ ) aham is put after the finite verb, and seems to be more or less united with the verb (puccheyyām' aham D I 51,3).

Y) aham is used twice in one sentence, as pronoun and as adherence to the verb ending (aham tena samayena ... isseram vattayām' aham, Bv 26,19).

$\delta)$ the beginning of the analytic optative, in which aham adheres directly to the conjugated optative with the sandhi, or with the elision of a vowel (jahe aham, Ja III 14,15*; yadi 'ham labhe, Cp 131; kareyy'aham, Cp 218).

ع) -ahạ̣ replaces -āmi (tasmā tāta palāyaham, Ja II 340,9*).

Judging from this CPD's scheme, Smith seems to have enlarged his concept of the analytic and coalescent conjugations after his article in 1932. And Smith's categorization appears that this could be a description of the "chronological" order, how the analytic and coalescent conjugations developed. But we still need to collect their examples and to re-examine them. We here want to handle Smith's categorization independently from the chronology of the language.

As Smith $(1932,170)$ already suggests, the gap in the conjugation could be the main reason for this analytic/coalescent conjugation. For example, because of the uniform optative like jahe, the paradigm is more or less broken: $1 \mathrm{sg}$.jahe / $3 \mathrm{sg}$. jahe. Therefore it appears to be unavoidable that the personal pronoun takes over the roll of verb ending in order to make it clear, who utters a sentence: $1 \mathrm{sg}$.jahe / $3 \mathrm{sg}$.jahe $\rightarrow 1 \mathrm{sg}$.jahe aham / $3 \mathrm{sg}$. jahe. This idea of the compensation of the broken paradigm is certainly convincing. 
Nevertheless we can find so many examples of the analytic and coalescent conjugations of the indicative present, whose paradigm does not have a gap. If the compensation of the broken paradigm should be the one and only reason, then the indicative present would not need the analytic and coalescent conjugations. Consequently it seems that there should be another reason for the analytic and coalescent conjugations than the compensation of the broken paradigm. ${ }^{3)}$

\section{Analysis of the Coalescent Conjugation in Pāli}

Hereafter we examine the syntactic roll of the coalescent and analytic conjugations. Because the word order in the verse-text is very free, so only the prosetext can be "syntactically" examined. Generally the coalescent conjugation occurs in the following context.

\section{Question-Answer}

D II $234,20-21$

6 Kṣatriyas: sarati bhavan tam vacanam?

King Reṇu: sarām' aham bho tam vacanam.

"Does my lord remember your word?"

"Gentlemen, I remember my word." (Walshe: D trans. 305.)

In this example, 6 Kșatriyas ask specially to the King Renu, "Do you remember?" Then the King Renu answers "I do remember." The emphasis is lied on the act of remembering, but, because the King Renu is asked personally, he wants to indicate that he himself remembers the promise.

\section{A $1230,22-23$}

Buddha: sakkhasi panna tvam bhikkhu tīsu sikkhāsu sikkhitum?

A Bhikkhu: sakkomaham bhante tisu sikkhāsu sikkhitum...

"Can you train in the three trainings, bhikkhu ..?"

"I can, Bhante."

(Bhikkhu Bodhi: A trans. 316.)

Like the D-example, the question is asked to a certain monk personally. The asked monk uses the coalescent conjugation, sakkomaham.

For a comparison, an example with interrogative pronoun is given:

Vin I 55,31-34 
Buddha: Ko nu kho bhikkhave tassa brāhmanassa adhikāram sarati? Sāriputta: aham kho, bhante, tassa brāhmanassa adhikāram sarāmi.

"Who remembers a service done by this brahman?"

"I, Lord, remember a service done by this brahman." (Horner: Vin trans. IV 72)

In this Vin-example, the Buddha asks several monks indefinitely, "Who remembers ... ?" Then Sāriputta answers "I remember." In this case the analytic or coalescent conjugation does not occur.

Consequently the difference becomes clear: When a speaker is asked personally whether she/he undertakes a certain action, or not, then she/he answers with the coalescent conjugation. On the contrary, when she/he is asked with interrogative pronoun "Who ...??" i.e., the agent itself is unknown, then the coalescent conjugation is not used.

\section{Expression of the Intension}

Vin I 32,38-33,1

Uruvelakassapa: icchām' aham bho mahāsamaṇe brahmacariyam caritum.

"I want, good sirs, to fare the Brahma-faring under the great recluse" (Horner: Vin trans. IV 43)

This sentence is uttered by Uruvelakassapa on the occasion of his conversion to Buddhism. He, using the coalescent conjugation, expresses more apparently that he himself wishes to fare the brahma-faring, i.e., to convert to Buddhism.

\section{Vin IV 292,9}

Bhaddā Kāpilānī: sace me ayyā Thullanandā upassayạ̣ dadeyya, āgaccheyyām' aham Sāvatthim.

"If the lady Thullanandā would give me quarters, I would come to Sāvatthī" (Horner: Vin trans. III 311)

The example indicates that the nun Bhaddā Kāpilānī expresses her own wish to go to Sāvatthī, because of her business in Sāvatthì. And thus, she, using the coalescent conjugation, indicates that she herself is wishing.

For a comparison, another example from Vin without coalescent conjugation is given:

Vin I 139,29

Buddha: so ce bhikkhūnam santike dūtam pahineyya, "āgacchantu bhaddantā, icchāmi dānañ ca dātum..."ti. 
"If he (= a layfollower) should send a message to monks, saying: 'Let the revered sirs come, I want to give a gift."' (Horner: Vin trans. IV 186)

This is uttered by the Buddha on the occasion, that, if a building has been built by a layfollower in order to invite monks, and if the business there can be done in seven days, they can visit this layfollower. So, the subject in this sentence is a supposed person in a supposed situation. In this case the Buddha does not use the coalescent conjugation, for he does not need to indicate that especially this supposed layfollower is wishing.

The difference is somehow readable, although less obviously than the questionanswer examples: When a speaker express her/his personal intension, then she/he uses the coalescent conjugation. On the contrary, a speaker describing a supposed intension of a supposed person, then he does not use the coalescent conjugation.

\section{Topic and Topicalization}

From all the examples, we can observe the following: When a speaker is describing her/his own personal circumstance, i.e., she/he is talking about herself/himself, then she/he uses the coalescent form. In other words, the speaker uses the coalescent conjugation in order to make it clear that she/he is describing herself/himself in a certain limited and personal situation, i.e., she/he is making herself/himself a "topic" of the sentence. Consequently we can define this phenomenon as "topicalization" of the first pronoun. The words, "topic" and "topicalization" are used here in the linguistic sense; ${ }^{4)}$ the topic means what is being described in a sentence of a speaker. That is, the object of the description in a sentence (not in a discourse). And the topicalization means the attempt of the speaker to make a certain word/phrase the topic of his/her sentence. The topicalization is possible in various means. One example in English is as follows:

The dog bit the little girl.

$\rightarrow$ As for the little girl, the dog bit her.

In this case, the object of the first sentence, the little girl, is topicalized in the second. In this manner, the speaker make it clear that he is describing the little girl. Generally each word or phrase in a sentence can be topicalized. With the help of the 
"topicalization," a speaker can exactly depict what does she/he concern in her/his sentence.

On this linguistic point of view, the aforementioned examples can be syntactically reanalyzed; the first person as subject, i.e., the speaker for herself/himself, is topicalized. In other words, she/he makes it clear that she/he is describing herself/himself under her/his personal situation, like answering a personally asked question or describing a personal intension.

To sum up, it is very likely that the analytic and coalescent conjugations in Pâli have the function of the "topicalization," which allows a speaker to make it clear whom she/he is describing in a sentence.

Furthermore, it is also very likely that this topicalizing function is possibly forgotten in a course of time. When the origin falls into oblivion, the speakers of the Middle Indic do not hesitate to treat the analytic and coalescent conjugations, especially for the first person, as alternative conjugation to the grammatically "regular" conjugation.

The syntactic point of view can help us to re-examine the origin of the analytic and coalescent conjugations. It, however, is very difficult to analyze examples in verse, for the conditions of the prosody (metre, the number of syllables, word order and so on), obstruct the syntactic investigation.

\section{Conclusion}

As we investigate mainly the coalescent conjugation in Pāli prose, The following is to be observed: When a speaker wants to make herself/himself "topic" in a sentence, i.e., to indicate more apparently that she/he is describing herself/himself, then she/he uses the coalescent conjugation. At now, the origin of the analytic and coalescent conjugations is discussed only on the morphological level, i.e., they are created in order to bridge the gaps in the verb paradigm. But we need to reconsider this problem from the syntactic point of view.

\section{Notes}

1) See also Bloch 1932. On the other hand, Pisani (1952) criticizes that the way of Smith's argument could reverse the linguistic chronology, and that this phenomenon in Pāli should be regarded as the origin of the ending of the first-person of the Apabhramśa. But Pisani (1952) criticizes only the way of Smith's argument and admits that the personal pronoun of the first- 
person is used for the verb ending.

2) Bechert (1958) reports further forms of the analytic/coalescent conjugations in Ap.

3) Concerning the overview of the analytic and coalescent conjugation, see also Überblick $\S 421$; 434; 441.

4) On the terms, topic and topicalization, the author depends on: Givón 1983.

\section{Abbreviations}

A

Ap

Aśoka

Bhikkhu Bodhi: A trans.

$\mathrm{Bv}$

$\mathrm{Cp}$

CPD

D

Horner: Vin trans.

Ja

Mvu

Vin

Sn

Thì

Überblick

Walshe: D trans.
Añguttaranikāya. Morris, Richard, and Edmund Hardy, eds. The AnguttaraNikāya. 6 vols. London: Pali Text Society, 1885-1910.

Apadāna. Lilley, Mary E., ed. The Apadāna of the Khuddaka Nikāya. London: Pali Text Society, 1925-1927.

Inscriptions of Aśoka. Bloch, Jules, ed. Les inscriptions d'Aśoka. Paris: Les Belles Lettres, 1950.

Bhukkhu Bodhi, trans. The Numerical Discourses of the Buddha: A Translation of the Anguttara Nikāya. Boston: Wisdom Publication, 2012.

Buddhavamsa. Jayawickrama, Nicholas Abedheera, ed. Buddhavamsa and Cariyāpitaka. London: Pali Text Society, 1974.

Cariyāpițaka. Jayawickrama, Nicholas Abedheera, ed. Buddhavamsa and Cariyāpițaka. London: Pali Text Society, 1974.

Trenckner, Vilhelm et al., eds. A Critical Päli Dictionary. Copenhagen: Munksgaard, 1924-2011.

Dīghanikāya. Davids, Thomas William Rhys, and Joseph Estlin Carpenter, eds. The Digha Nikāya. London: Pali Text Society by Luzac, 1890-1911.

Horner, Isaline Blew, trans. The Book of the Discipline. 6 vols. London: Pali Text Society, 1938-1966.

Jātaka. Fausbøll, Viggo, ed. The Jātaka. London: Trübner, 1877-1897.

Mahāvastu. Senart, Émile, ed. Le Mahâvastu. 3 vols. Paris: Imprimerie nationale, 1882-1897.

Oldenberg, Hermann, ed. The Vinaya Pitaka. 5 vols. London: Pali Text Society, 1969-1984 (1st ed., 1879-1883).

Suttanipāta. Andersen, Dines, and Helmer Smith, eds. The Sutta-Nipāta. Oxford: Pali Text Society, 1913.

Therīgāthā. Oldenberg, Hermann, and Richard Pischel, eds. The Theraand Therî-gâthâ. Oxford: Pali Text Society, 1990.

von Hinüber, Oskar. Das ältere Mittelindisch im Überblick. 2. erw. Aufl. Wien: Verlag der Österreichischen Akademie der Wissenschaften, 2001.

Walshe, Maurice, trans. The Long Discourses of the Buddha: A Translation of the Digha Nikāya. 2nd ed. Boston: Wisdom Publication, 1995. 


\section{Literature}

Bechert, Heinz. 1958. "Grammatisches aus dem Apadānabuch." Zeitschrift der Deutschen Morgenländischen Gesellschaft 108: 308-316.

Bloch, Jules. 1932. "Survivance de skr. āsìt en indien moderne." Bulletin de la société de linguistique de paris 33: $55-63$.

Givón, Talmy, ed. 1983. Topic Continuity in Discourse: A Quantitative Cross-Language Study. Amsterdam: John Benjamins Publishing Company.

Pisani, Vittore. 1952. "Noterelle Pāli." Rendiconti dell'Istituto Lombardo di scienze e lettere 85: 1-10.

Smith, Helmer. 1932. "Désinences verbales de type Apabhramça en Pāli." Bulletin de la société de linguistique de paris 33: 169-172.

Key words Pāli, Linguistics, Syntax, Morphology

(Research Fellow, Dhammachai Tipitaka Project, PhD)

\section{New Publication}

\section{BDK Tripițaka Translation Series}

\section{The Canonical Book of the Buddha's}

Lengthy Discourses

\section{Volume I}

（長阿含經 卷一～九）

Translated by Shohei Ichimura

$15.6 \times 23.1 \mathrm{~cm}, 375$ pp., $¥ 6,480$ (\$60)

Bukkyo Dendo Kyokai, 2015

(Society for the Promotion of Buddhism) 